\section{Татьяна Викторовна Панюкова \\ ведущий редактор Издательства, младший научный сотрудник \\ кафедры русской литературы и журналистики Петрозаводского государственного университета \\ (Петрозаводск, Российская Федераиия)}

aurinko75@mail.ru

\title{
ПРИМЕЧАНИЯ А. Г. ДОСТОЕВСКОЙ К ПРОИЗВЕДЕНИЯМ Ф. М. ДОСТОЕВСКОГО (две редакции)*
}

Аннотация. В публикации сопоставляются две известные на данный момент редакции (черновая и беловая) примечаний Анны Григорьевны Достоевской к произведениям ее мужа, сделанные ею в 1904-1906 годах на гранках последнего, седьмого, издания Полного собрания сочинений Ф. М. Достоевского, а позже перенесенные на страницы некоторых томов данного ПСС. Черновая редакция печатается впервые. Текст беловой редакции печатается полностью, с исправлениями неточностей первых публикаций, в авторской орфографии и пунктуации. Некоторые примечания снабжены комментарием.

Ключевые слова: А. Г. Достоевская, Ф. М. Достоевский, «Музей памяти», примечания, редакции, Полное собрание сочинений, издательская и музейная деятельность

3 начение примечаний А. Г. Достоевской исчерпывающе полно и точно охарактеризовал их первый публикатор Леонид Петрович Гроссман: они «представляют крупный интерес в качестве биографического и историко-литературного комментария, проливающего значительный свет в темную область приемов творчества и художественной техники Достоевского» $[13,4-5]$. Несмотря на это бесспорное суждение, до сих пор мало внимания обращал на себя тот факт, что примечания Анны Григорьевны Достоевской к произведениям мужа существуют, как минимум, в двух редакциях. Особенно остро эта проблема обозначилась при подготовке комментариев к роману «Бесы» для Полного собрания сочинений Ф. М. Достоевского в авторской орфографии и пунктуации [7] и при сверке цитат, когда обнаружились некоторые расхождения между рукописным оригинальным источником и вариантом, впервые опубликованном в начале 1920-х годов Л. П. Гроссманом

Последний вариант Примечаний теперь, конечно, наиболее известен и неоднократно воспроизводился в комментариях к произведениям Ф. М. Достоевского. Вот что пишет исследователь об истории этой публикации: «Подготовив к изданию в 1906 году, к 25-летней годовщине смерти Достоевского, полное собрание его сочинений ${ }^{2}$ А. Г. Достоевская не снабжала его какими либо примечаниями или справками. Но на одном из экземпляров этого издания она сделала на полях книг ряд заметок, представляющих 
высокий комментаторский интерес. С этого экземпляра, хранящегося в комнате Достоевского в Московском Историческом Музее воспроизводятся главные “маржиналии” А. Г. Достоевской, с указанием мест, вызвавших эти примечания. Страницы указаны всюду по Полному Собранию Сочинений Ф. М. Достоевского, изд. 7-ое, Спб., 1906. К этим “заметкам на полях" мы присоединили несколько аналогичных записей А. Г. Достоевской из ее тетради-каталога: "Книга для записывания книг и газет по моей библиотеке”, а также ряд соответственных выдержек из “Воспоминаний” вдовы писателя» [13, 54]; ср.: [14, 29].

Упомянутая «комната Достоевского» - первый музей Ф. М. Достоевского. Был создан, первоначально как «отдел Достоевского» А. Г. Достоевской в 1889 году, а официально открыт в 1891 году, к 10-й годовщине смерти писателя $\left[4,17-18^{3}\right]$, разместившись в одной из башенок Исторического музея в Москве. В мае 1906 года, после совершеннолетия детей Достоевских, вся коллекция официально вошла в состав Исторического музея как «Музей памяти Ф. М. Достоевского в Императорском Российском Историческом музее имени Императора Александра III в Москве» ${ }^{4}$ В том же году А. Г. Достоевская издала библиографический указатель ${ }^{5}$, в котором не описаны сделанные ею примечания к произведениям Ф. М. Достоевского ${ }^{6}$.

Л. П. Гроссман мог увидеть и скопировать Примечания к произведениям Ф. М. Достоевского либо весною 1917 года, когда он работал над рукописями писателя в Московском Историческом музее $[13,4]$, либо после переезда из Одессы в Москву в 1921 году7.

Еще раньше, осенью 1906 года, публицист Александр Сергеевич Глинка, работавший с материалами «Музея памяти», в письме к А. Г. Достоевской просит прислать ему для ознакомления, для будущей книги о писателе, некоторые недоступные в «Музее...» рукописи, среди которых упоминает и «/(копію)/ < ..> Ваших примтчаній к сочиненіям. (Новое /(6-ое) (14 т.) $<$ (>пучшее)/ изданіе я купил, так что указаніе страниц, если Вам удобно, лучше сдълать по нему)» ${ }^{8}$.

Часть коллекции А. Г. Достоевской, переданная в Исторический музей, хранилась там до 1929 года [12, 8]. В 1929 году «Музей памяти» Достоевского был закрыт, материалы его переданы в Государственную библиотеку им. В. И. Ленина (ГБЛ; ныне - Российская государственная библиотека), а впоследствии разделены. Рукописи продолжали храниться в ГБЛ, книги и документы были отправлены в Государственную публичную историческую библиотеку, а личные вещи, мебель и изобразительные материалы влились в коллекцию московского музея писателя на Божедомке (ныне ул. Достоевского). Этот музей, открытый 11 ноября 1928 года, в 1940 году был присоединен к Государственному литературному музею ${ }^{9}$. Именно тогда, вероятно, и произошло разделение изначально единого «белового» варианта Примечаний А. Г. Достоевской. На сегодняшний день «беловая» редакция Примечаний (далее: Прим2) находится в Москве в двух местах: 1) в «Музееквартире Ф. М. Достоевского ${ }^{10}$ (записи представляют собой изъятые из 
томов 7-го Полного собрания сочинений писателя листы с письменными комментариями Анны Григорьевны: т. IV («Униженные и Оскорбленные», «Вечный муж»), т. V («Преступление и Наказание»), т. VI («Идиот»), т. VII («Бесы»), т. X («Дневник Писателя за 1876 год»), т. XII («Братья Карамазовы»). По словам ведущего научного сотрудника ГЛМ Павла Евгеньевича Фокина, оказавшего нам помощь при розыске источника, «делать свои записи Анна Григорьевна, судя по всему, начала с тома, в котором опубликован роман “Идиот", на титуле которого есть некоторое подобие предисловия»); 2) в Российской государственной библиотеке (листы из т. III с записями, относящимися к «Запискам из Мертвого Дома») [12, 538]; [4, 104].

Первоначальная, черновая редакция Примечаний А. Г. Достоевской к некоторым произведениям своего мужа, сделанных ею на полях корректурных гранок 7-го (1904-1906) издания ПСС Достоевского, мало известна. Она находится ныне в фонде Пушкинского Дома в отделе рукописей, где «хранится бо́льшая часть личного архива А. Г. Достоевской» $[4,30]$ (РО ИРЛИ. Ф. 100. № 29602) [12, 538]; [4, 108], и представляет собой отдельные печатные листки (гранки) со страницами из комментируемых произведений, сшитые в одну тетрадь с общей сквозной пагинацией. Всего в тетради 104 листа. Комментируемые произведения располагаются в ней не в хронологическом порядке, не в порядке выхода томов и не в порядке написания примечаний к произведениям ${ }^{11}$ : л. $1-<$ Предисловие Анны Григорьевны (первоначальный вариант)>; л. 1 об.-15 об. - «Идиот» (т. 6, 1904); л. 16-27 об. — «Бесы» (т. 7, 1905); л. 28-33 об. - «Униженные и Оскорбленные» (т. 4, 1904); л. 3450 об. - «Преступление и Наказание» (т. 5, 1904); л. 51-69 об. - «Братья Карамазовы» (т. 12, 1906); л. 70-76 об. - «Вечный муж» (т. 4, 1904); л. 77104 об. - «Дневник Писателя за 1876 год» (т. 10, 1905). Помимо примечаний Анны Григорьевны, на этих страницах присутствует также корректорская правка, внесенная в окончательный вариант ПСС (см. илл. 1 и 2).

Данная редакция Примечаний, скорее всего, относится к той части архива Анны Григорьевны, которая хранилась не в созданном ею «Музее памяти», а дома или в банковских сейфах ${ }^{12}$. Описывая основные места хранения рукописного наследия семьи Достоевских в крупнейших архивохранилищах страны, В. С. Нечаева писала: «Третья (после НИОР РГБ и РГАЛИ ${ }^{13}$. - Т. П.) значительная часть архива Ф. М. Достоевского хранится в Ленинграде, в Рукописном отделе Института русской литературы Академии наук СССР (Пушкинский дом). Она, очевидно, тоже относится к собранию А. Г. Достоевской, но история ее отделения от частей, хранящихся в Москве, неясна. В Пушкинский дом она поступила в 1920 и 1921 гг. из отдела по учету и охране памятников старины. Здесь оказались рукописи к романам Достоевского и к “Дневнику писателя”, письма как самого Ф. М. Достоевского, так и многочисленные письма к нему, а также его деловые бумаги. Особенно значительна здесь часть архива А. Г. Достоевской, состоящая из ее записных книжек, переписки, деловых бумаг и т. п.» [12, $10-11]$. 


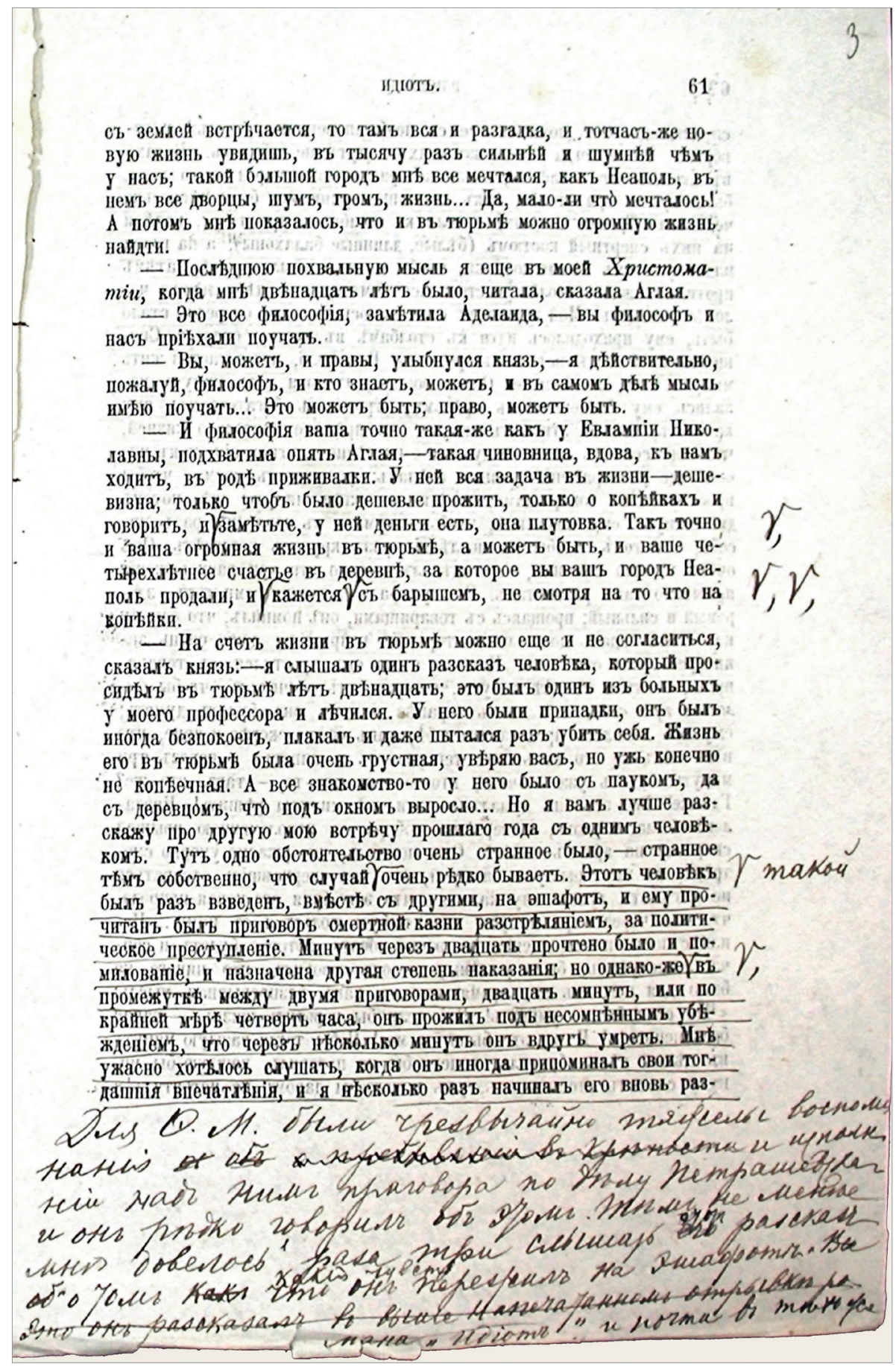

Илл. 1. РО ИРЛИ. Ф. 100. № 29602. Л. 3 
съ зем.епі встрғчаетея, то тамь вея п разга:қа, и тотчась-же но-

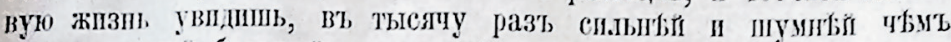

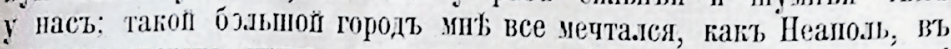

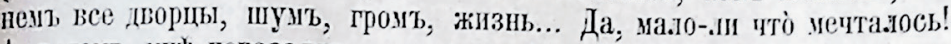

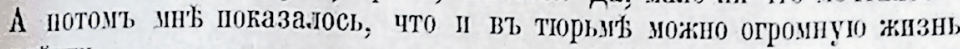
наfígTII.

- Ilосльднго похвальнуо мыс.п я еще въ моеп̆ Христома-

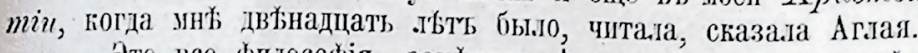

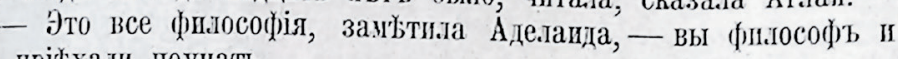
насъ пріъхалІі поучать.

- Вы, можеть, п правы, улыбнулся князь, 一я дыниствительно, пожалуй, фнлософь, и кто знаеть, можеть, п вт саномь дъ.'ъ мысль имью поучать... Это зожеть быть; право, можеть оыть.

- Й финособқія вапа точно такая-же какь у Ев.ампіп Нпкојавны, подхватнла оплть Аглая,-такая чиновнпца, вдова, нъ намъ ходить, въ родъ прпжпвалки. $\grave{y}$ ней вся задача в'ъ жизни-дешевизна; только чтобъ было депевле прожить, только 0 копьнкахъ ІІ говорить, п, замьтьте, у ней деньги есть, она плутовка. Таюъ точно и ваша огромная жізны въ тірьм', а можеть быть, п ваше четырехльтнее счастье въ деревнћ, за которое вы вашь городъ Неаполь продали, и, кажется, съ барыпемь, не смотря на то что на हonthitill.

- На счетъ жизни въ тюрьмॐ можно еще II не согласиться, сказаль князь:-я слышалъ одинъ разсказъ человТка, который про-

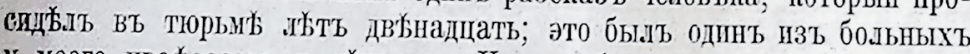

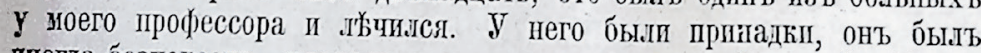
вногда безпокоенъ, плакаль и даже пытағся разъ уобить себ́я. Жизнь его въ тторьнь была очень грустнал, увъряю васъ, но ужь конечно не коптечнал. А все знакомство-то у него было сь паукомь, да съ деревцомъ, что̀ подъ окномь выросло... Но я вамъ лучште раз-

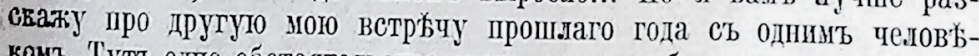
комъ. Тутъ одно обстоятельство очень странное было, странное тьмъ

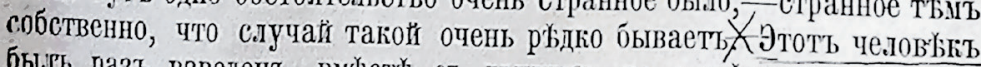
быгь разъ взведенъ, вмбстуь сь другим, на эшафоть, и ему прочвтань бы.ы приговорь смертной казни разстрьляніемь, за политн-

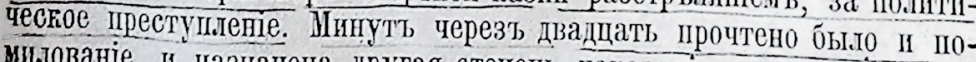
миловані., и назначена другая степень наказанія; но однако-же, въ

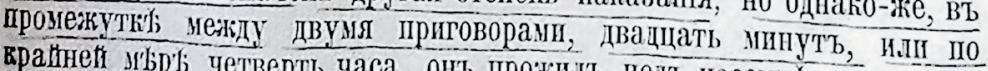

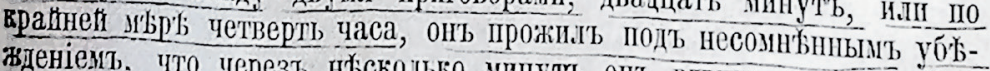

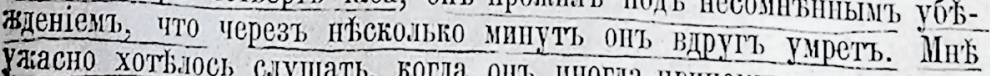

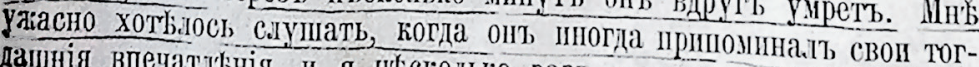

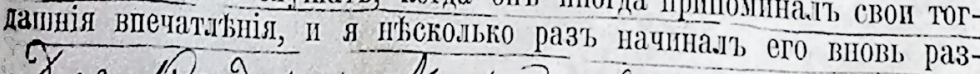

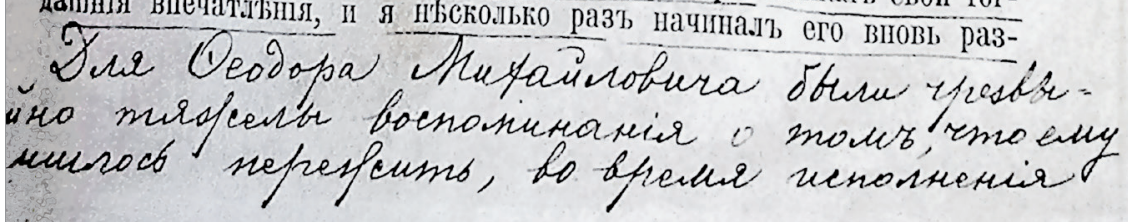

Илл. 2. ГЛМ. Примечание к роману «Идиот» 
В беловом варианте Примечаний к произведениям Ф. М. Достоевского отсутствует характерная для чернового автографа правка текста (зачеркивания, вставки), расшифрованы отдельные имена, уточнены некоторые детали; также при переписывании набело в Примечания была внесена небольшая стилистическая и, возможно, автоцензурная, правка. Помимо текстуальных различий между каждым отдельным примечанием (которые будут видны из приводимой в <Приложении > сводной таблицы), можно отметить, что в беловой редакции имеются несколько примечаний, вероятно, написанных позднее, отсутствующих в черновом варианте: к «Запискам из Мертвого Дома», а также один комментарий к роману «Бесы», касающийся посещения Достоевским юродивого Корейши (см. об этом подробнее: [7, 796-797]), и один комментарий к «Братьям Карамазовым» (по поводу книги «Сто четыре священные истории...»).

\section{ПРИМЕЧАНИЯ}

* Исследование выполнено по гранту Министерства образования и науки России «Новые источниковедческие и текстологические исследования русской словесности XIXХХ вв.» (№ 34.1126).

1 Первая публикация в сб.: Творчество Достоевского. 1821-1881-1921. Одесса, 1921. С. 29-35. Далее: Прим1. Неполная (отсутствуют <Предисловие>, примечания к «Запискам из Мертвого Дома» и роману «Идиот»), с пропусками и неточностями в остальных Примечаниях; в орфографии подлинника.

Вторая публикация в кн.: Гроссман Л. П. Семинарий по Достоевскому: материалы, библиография и комментарии. М.; Пг., 1922. С. 54-69 (на обложке другой год: 1923). Далее: Прим2. В современной орфографии. Здесь, по словам Л. П. Гроссмана, примечания А. Г. Достоевской были воспроизведены «с значительными дополнениями, исчерпывающими весь состав этих рукописных заметок». Небольшие неточности и лакуны, все же встретившиеся во второй публикации исследователя, оговорены в сносках к «беловой» редакции Примечаний (см. <Приложение >).

2 Всего после смерти писателя его вдовой было подготовлено и издано семь Полных собраний сочинений Ф. М. Достоевского: изд. 1-е (1882-1883), в 14 т., в тип. бр. Пантелеевых и А. С. Суворина, 6000 экз. (тт. 6 и 7, с романами «Преступление и Наказание» и «Идиот», переизданы в 1884 году); изд. 2-е (1885), в 6 т., в тип. А. С. Суворина, 6000 экз. (большого формата, в 2 столбца, более дешевое, разошлось за два года); изд. 3-е (18881889), в 12 т., в тип. бр. Пантелеевых, 12000 экз., (дешевое, распродано за 2,5 года); изд. 4-е (1891-1892), в 12 т., тип. бр. Пантелеевых; изд. 5-е (1894-1895), в 12 т. (24 кн.), (издание А. Ф. Маркса; права на издание были проданы Марксу на два года, до 1 января 1896 года); изд. 6-е (юбилейное) (1904-1906), в 14 т.; изд. 7-е (1904-1906), в 12 т. (более дешевое). О последних двух ПСС, издававшихся параллельно, Анна Григорьевна писала: «На этот раз, ввиду наступавшей старости, я решила выпустить в свет роскошное издание Полного собрания сочинений Ф. М. Достоевского, напечатанное на веленевой бумаге, новым крупным шрифтом, с приложением доселе не появлявшихся в печати видов и портретов, составлявших наши семейные реликвии. Я назвала это издание юбилейным, так как оно должно было появиться в 1906 году (и появилось) к дню печального юбилея, к двадцатипятилетию со дня кончины моего мужа. <...> Одновременно с юбилейным изданием Полного собрания сочинений я издала 7-е, тоже 
изящное, напечатанное на прекрасной бумаге и четким новым шрифтом, за цену 10 рублей за 12 томов. Этими двумя изданиями я закончила свою издательскую деятельность, продолжавшуюся 38 лет (1872-1910 гг.)» [5, 574-575] (подробное описание издательской деятельности А. Г. Достоевской после смерти писателя можно найти в последнем (полном) издании ее воспоминаний [5, 480-489, 541-554, 574-587], главы «1881 год. Первое Полное собрание сочинений Ф. М. Достоевского», «Продажа прав “Ниве”. 1904», «Два последние издания Полного собрания сочинений»). См. также: [10]. На гранках (черновой вариант) и на вырванных из томов ПСС страницах (беловой вариант) этого последнего 7-го издания и была сделана основная часть Примечаний А. Г. Достоевской к произведениям мужа (часть Примечаний - на гранках к 6-му юбилейному изданию).

См. также: [1]; [2]; [3]; [6]; [9]; [11]; [15].

4 См. протокол передачи: РГАЛИ. Ф. 212. Оп. 1. Д. 240.

5 Он вышел в двух идентичных изданиях: «Библіографическій указатель сочиненій и произведеній искусства, относящихся къ жизни и дъятельности Ө. М. Достоевскаго, собранныхъ въ “Музеъ памяти Ө. М. Достоевскаго” въ Московскомъ Историческомъ Музеъ Имени Императора Александра III. 1846-1903 гг.» и «Музей памяти Өеодора Михайловича Достоевскаго въ Императорскомъ Россійскомъ Историческомъ музеъ имени Императора Александра III въ Москвъ. 1846-1903 гг.» (Составила А. Достоевская. Съ портретами и видами. С.-Петербургъ: Типографія П. Ө. Пантелъева, 1906. 392, [2] с.; то же издание, что и предыдущее, но на веленевой бумаге и с пятью приложениями) $[4,27]$.

6 В 1916 году Анна Григорьевна писала: «Къ 1906 году, т. е. ко времени окончательной передачи въ въденіе Историческаго Музея пожертвованнаго мною собранія въ немъ числилось, согласно каталогу 4232 самыхъ разнообразныхъ предмет[овъ]/а/. [Съ того времени накопилось у меня по меньшей мъръ около 3000 выръзокъ изъ газетъ, портретовъ, книгъ и пр. Все это ежегодно пересылалось мною въ Москву, но оставалось недоступнымъ для публики. Мнъ хотълось привести все присланное въ порядокъ и по реестру сдать Музею. Къ сожалънію, /пока этого не случилось:/ въ теченіи послъднихъ десяти льтъ я была занята сначала изданіями двухъ Полныхъ Собраній Сочиненій (юбилейнаго и $7^{\text {го }}$ ) а затъмъ приведеніемъ въ порядокъ нъсколько заброшенныхъ мною личныхъ дълъ»; «за десять льтъ, прошедшихъ со времени передачи Музея у меня /накопилась/ масса матеріала >...> Часть этого матеріала отправлена въ Историческій Музей, большая часть хранится въ кладовой въ сундукахъ, среди моихъ вещей. Мое задушевное желаніе это - имъть <...> силы и время что бы составить карточки на все имъющееся <...> и все направить въ Музей; съ карточекъ же отпечатать продолженіе “Библіографическаго Указателя", если не въ видъ отдъльной книги, то въ видъ приложенія къ какому нибудь историческому журналу. Буду надъяться, что судьба дозволитъ мнъ привести въ исполненіе это мое задушевное желаніе» $[4 ; 60,63,41]$.

7 Однако собранные Анной Григорьевной в одной из комнат огромного здания Исторического музея сокровища «не были рассчитаны на публичное обозрение и не представляли музейной экспозиции. Хранитель <...> выдавал специалистам научно необходимые материалы и справки для их работ, но о более широком ознакомлении с этим собранием речи быть не могло из-за условий его хранения и организации помещения» $[11,278]$.

8 См.: НИОР РГБ. Ф. 93.ІІ.2.92. Л. 9. Письмо из Симбирска от 3 ноября 1906 года. Александр Сергеевич Глинка (1878, Симбирск - 1940) - русский журналист, публицист, литературный критик, историк литературы, религиозный мыслитель; печатался 
также под псевдонимом Волжский. Издал в Санкт-Петербурге в 1902 году «Два очерка об Успенском и Достоевском», в журнале «Мир Божий» - статьи о Достоевском (1905, № 6-8), в 1906 году - книгу «Федор Михайлович Достоевский. Жизнь и проповедь» (СПб., книжный магазин Д. П. Ефимова, 79 с.). В РГАЛИ (Ф. 142. Оп. 1) хранится большой неопубликованный труд Волжского «Жизнь и творчество Достоевского» (ед. хр. 58-64), который Розанов, друживший с ним, безуспешно пытался помочь ему опубликовать (см.: [8, 289-292]), а также: рукопись статьи «Жизнь Ф. М. Достоевского и его религиозный смысл» (ед. хр. 382); письма издательства и книжного склада М. В. Пирожкова по поводу издания биографии Достоевского (ед. хр. 339); ответное письмо А. Г. Достоевской А. С. Глинке от 3 октября 1906 года - периода работы публициста в «Музее памяти» (ед. хр. 217. 2 л.), несколько статей о Достоевском и его творчестве (ед. хр. 65-77), в том числе и статья о «Музее памяти Достоевского» (ед. хр. 73. 18 л.). Углубленное чтение и изучение творчества и биографии Достоевского стало для молодого писателя одной из решающих вех в его «духовной родословной». По словам самого Глинки, «в Достоевском и в том, что за ним и около него, я пережил свой собственный личный кризис рационализма и сознательно и свободно пошел к подлинной религии, не чураясь метафизики и не боясь мистики» (Венгеров С. Глинка, Александр Сергеевич // Энциклопедический словарь Брокгауза и Ефрона [Электронный ресурс]. URL: https://ru.wikisource.org/wiki/\%D0\%AD\%D0\%A1\%D0\%91\%D0\%95/\%D0\% 93\%D0\%BB\%D0\%B 8\%D0\%BD\%D0\%BA\%D0\%B0,_\%D0\%90\%D0\%BB\%D0\%B5\% D0\%BA\%D1\%81\%D0\%B0\%D0\%BD\%D0\%B4\%D1\%80_\%D0\%A1\%D0\%B5\%D1\%80\% D0\%B3\%D0\%B5\%D0\%B5\%D0\%B2\%D0\%B8\%D1\%87

9 Организован в 1927-1928 годах В. С. Нечаевой, ставшей первым директором музеяквартиры; открыт 11 ноября 1928 года ко дню рождения писателя; в 1940 году вошел в состав Государственного литературного музея. См. также: http:/goslitmuz.ru/ collections/370/

${ }^{10}$ См. на сайте музея: «Собрание А. Г. Достоевской: издание седьмое [А. Г. Достоевской]. В 12-ти тт. СПб., 1904-1906. Тт. 4-7, 10, 12 с пометами и примечаниями А. Г. Достоевской. Инв. №№ 174702, 174703, 174705, 174706, 142271» [10].

11 По указанию самой Анны Григорьевны, началось всё в 1904 году, когда «при прочтеніи корректуръ седьмаго изданія» она «успъла сдълать замътки къ двумъ романам<ъ>: Униж<енные и Оскорбленные> и Идіотъ» (РО ИРЛИ. Ф. 100. № 29602. Л. 1).

12 «Передавая лишь частично рукописи на хранение в Исторический музей, она большую их часть хранила дома в шкафу или в сейфах банка» [12, 7].

13 Уезжая в 1917 году из Петербурга на Кавказ, А. Г. Достоевская сдала часть рукописей «на хранение в сейф одного из банков в особом ящике из белой жести <...> По постановлению Совнаркома от 24 июня 1921 г. Наркомфин обязан был передать все рукописные материалы, хранившиеся в сейфах, заместителю наркома просвещения М. Н. Покровскому, и 8 ноября того же года Центрархивом были получены от Госхрана сведения, что среди различных документов делового характера в сейфе обнаружены рукописные материалы, принадлежавшие Ф. М. Достоевскому. 12 ноября 1921 г. ящик с материалами Достоевского был вскрыт в Центрархиве в присутствии специально назначенной комиссии, составлен акт и краткий перечень содержимого ящика». Эти рукописи, а также часть ее архива, вывезенная в 1920-е годы после смерти А. Г. Достоевской с Кавказа и Крыма, составили ядро Центрархива, пополнившегося также перепиской Достоевских, присланной из Старой Руссы, и хранятся ныне в Российском государственном архиве литературы и искусства (РГАЛИ) в Москве [12, 9-10]. 


\section{СПИСОК ЛИТЕРАТУРЫ}

1. Андрианова, И. С. Виртуальный «Музей памяти Ф. М. Достоевского» : от проекта А. Г. Достоевской - к современному исполнению / И. С. Андрианова // Актуальные проблемы источниковедения и текстологии в контексте современных информационных технологий : материалы Всероссийской научной конференции, посвященной 100-летию со дня основания Государственного музея Л. Н. Толстого. - Москва, 2011. С. $43-47$.

2. Андрианова, И. С. Судьба семейного архива Достоевских / И. С. Андрианова // Историко-культурный и экономический потенциал России : наследие и современность : материалы Международной научно-практической конференции 14-15 мая 2012 года. Великий Новгород, 2012. - С. 70-75.

3. Андрианова, И. С. Коллекции Анны Достоевской. Новые материалы об истории возникновения «Музея памяти Ф. М. Достоевского» / И. С. Андрианова // Историкокультурный и экономический потенциал России : наследие и современность : материалы Международной научно-практической конференции 2013 года. - Великий Новгород, 2013. - С. 105-111.

4. Андрианова, И. С. «Музей памяти Ф. М. Достоевского» : история и перспективы проекта / И. С. Андрианова. - Петрозаводск : Изд-во ПетрГУ, 2013. - 192 с.

5. Достоевская, А. Г. Воспоминания. 1846-1917 / А. Г. Достоевская. - Москва : ООО «Бослен», 2015. - 768 с.

6. Достоевская, А. Г. Воспоминания. Последняя редакция 1911-1916 гг. - [Электронный pecypc] / ПетрГУ. — URL : http://philolog.petrsu.ru/agdost/vospomin/vospomin.htm (12.02.2016).

7. Достоевский, Ф. М. Полное собрание сочинений : канонические тексты / Ф. М. Достоевский / под ред. проф. В. Н. Захарова. - Т. 9. - Петрозаводск : Изд-во ПетрГУ, 2012. - С. 711-853.

8. Из архива А. Г. Достоевской : Письма Д. С. Мережковского и С. Н. Булгакова. Переписка с В. В. Розановым / публ. Э. Гарэтто // Минувшее : исторический альманах. Москва ; Санкт-Петербург, 1992. - Вып. 9. - С. 235-293.

9. Коган, Г. Ф. Из истории московского музея Достоевского / Г. Ф. Коган // Достоевский. Материалы и исследования. - Вып. 7. - Ленинград, 1987. - С. 210-226.

10. Мир Достоевского. Каталог юбилейной выставки (1996-2000). Рукописи, книги, изобразительные материалы, памятные вещи из фонда Ф. М. Достоевского [Электронный ресурс]. — Ч. 5. — URL : http://old.goslitmuz.ru/goslitmuz.ru/ru/index.php?option=com content\&view=article\&id=1064 (12.02.2016).

11. Нечаева, В. С. Из воспоминаний об истории основания первого музея Ф. М. Достоевского / В. С. Нечаева // Достоевский. Материалы и исследования. - Вып. 6. - Ленинград, 1985. - С. 274-295.

12. Описание рукописей Ф. М. Достоевского / под ред. В. С. Нечаевой. - Москва, 1957. - 588 с.

13. Примечания А. Г. Достоевской к сочинениям Ф. М. Достоевского // Гроссман, Л. П. Семинарий по Достоевскому : материалы, библиография и комментарии / Л. П. Гроссман. - Москва ; Петроград : Государственное издательство, 1922. - С. 54-69.

14. Примечания А. Г. Достоевской к сочинениям Ф. М. Достоевского // Творчество Достоевского (1821-1881-1921) : сборник статей и материалов / под ред. Л. П. Гроссмана. - Одесса : Всеукраинское гос. изд-во, 1921. - С. 29-35.

15. Ярышева, И. С. Из истории «Музея памяти Ф. М. Достоевского» (Музейная деятельность вдовы Ф. М. Достоевского. По неопубликованным материалам) / И. С. Ярышева // Достоевский и современность : материалы XXII Международных чтений 2007 года. Великий Новгород, 2008. - С. 304-309. 
Tatyana V. Panyukova

Senior editor of the Publishing house of PetrSU, Junior researcher of the Department of Russian Literature and Journalism, Petrozavodsk State University, (Petrozavodsk, Russian Federation)

aurinko75@mail.ru

\title{
THE NOTES OF A. G. DOSTOEVSKAYA TO LITERARY WORKS OF F. M. DOSTOEVSKY (two editions)
}

\begin{abstract}
The article compares two editions of Anna G. Dostoevskya's notes that are known at this moment to her husband's literary works - the draft and final version. These notes were made by A. G. Dostoevskaya in 1904-1906 on the galley-proofs of the seventh edition of F. M. Dostoevsky's complete works and later, they were inserted in some volumes of the complete works. The draft edition is published for the first time. The text of the final version provides the corrected inaccuracies of the first publications and keeps author's spelling and punctuation intact. Some of the notes contain comments.
\end{abstract}

Key words: A. G. Dostoevskaya, Fyodor Dostoevsky, "Museum of memory", notes, editions, the Complete works, publishing and Museum activities

\section{REFERENCES}

1. Andrianova I. S. Virtual'nyy «Muzey pamyati F. M. Dostoevskogo» : ot proekta A. G. Dostoevskoy - k sovremennomu ispolneniyu [The Virtual "Museum to the Memory of F. Dostoevsky": from the Project of Anna G. Dostoevskaya to its Contemporary Implementation]. Aktual'nye problemy istochnikovedeniya i tekstologii $v$ kontekste sovremennykh informatsionnykh tekhnologiy: materialy Vserossiyskoy nauchnoy konferentsii, posvyashchennoy 100-letiyu so dnya osnovaniya Gosudarstvennogo muzeya L. N. Tolstogo [The Topical Problems of Source Studies and Textual Criticism in the Context of Modern Information Technologies: Proceedings of the All-Russian Scientific Conference Devoted to the 100th Anniversary of the Foundation of the Leo Tolstoy State Museum]. Moscow, 2011, pp. 43-47.

2. Andrianova I. S. Sud'ba semeynogo arkhiva Dostoevskikh [The Destiny of the Family Archive of the Dostoevskys]. Istoriko-kul'turnyy i ekonomicheskiy potentsial Rossii : nasledie i sovremennost': materialy Mezhdunarodnoy nauchno-prakticheskoy konferentsii 14-15 maya 2012 goda [Historical, Cultural and Economic Potential of Russia: The Heritage and the Present: Proceedings of the International Research and Practice Conference on May 14-15, 2012]. Veliky Novgorod, 2012, pp. 70-75.

3. Andrianova I. S. Kollektsii Anny Dostoevskoy. Novye materialy ob istorii vozniknoveniya «Muzeya pamyati F. M. Dostoevskogo» [Anna Dostoevskaya’s Collections. New Materials on the History of the Foundation of "The Museum to the Memory of Fyodor Dostoevsky"]. Istoriko-kul'turnyy i ekonomicheskiy potentsial Rossii : nasledie i sovremennost': materialy Mezhdunarodnoy nauchno-prakticheskoy konferentsii 14-15 maya 2012 goda [Historical, Cultural and Economic Potential of Russia: The Heritage and the Present: Proceedings of the International Research and Practice Conference, 2013]. Veliky Novgorod, 2013, pp. 105-111. 
4. Andrianova I. S. «Muzey pamyati F. M. Dostoevskogo»: istoriya i perspektivy proekta ["The Museum to the Memory of Fyodor M. Dostoevsky": History and Prospects of the Project]. Petrozavodsk, PetrSU Publ., 2013. 192 p.

5. Dostoevskaya A. G. Vospominaniya. 1846-1917 [Memoirs. 1846-1917]. Moscow, Boslen Publ., 2015. 768 p.

6. Dostoevskaya A. G. Vospominaniya. Poslednyaya redaktsiya 1911-1916 godov. [Memoirs. The Last Edition of 1911-1916]. Available at: http://philolog.petrsu.ru/agdost/vospomin/vospomin. htm (accessed 12 February 2016).

7. Dostoyevsky F. M. Polnoe sobranie sochineniy: kanonicheskie teksty [The Complete Works: Canonical Texts]. Petrozavodsk, PetrSU Publ., 2012, vol. 9, pp. 711-853.

8. Iz arkhiva A. G. Dostoevskoy : Pis'ma D. S. Merezhkovskogo i S. N. Bulgakova. Perepiska s V. V. Rozanovym. Publikatsiya E. Garetto [From the Archive of Anna G. Dostoevskaya: D. S. Merezhkovsky's and S. N. Bulgakov's Letters. Correspondence with V. V. Rozanov. Published by E. Garetto]. Minuvshee: istoricheskiy al'manakh [The Past: Historical Almanac]. Moscow, Saint-Petersburg, 1992, issue 9, pp. 235-293.

9. Kogan G. F. Iz istorii moskovskogo muzeya Dostoevskogo [From the History of the Dostoevsky Museum in Moscow]. Dostoevskiy. Materialy i issledovaniya [Dostoevsky. Materials and Researches]. Saint-Petersburg, 1987, vol. 7, pp. 210-226.

10. Mir Dostoevskogo. Katalog yubileynoy vystavki (1996-2000). Rukopisi, knigi, izobrazitel'nye materialy, pamyatnye veshchi iz fonda F. M. Dostoevskogo [Dostoevsky's World. A Catalog of the Anniversary Exhibition (1996-2000). Manuscripts, Books, the Graphic Materials, Memorabilia from the Fund of Fyodor M. Dostoevsky]. Available at: http://old.goslitmuz.ru/goslitmuz.ru/ru/ index.php?option=com_content\&view=article\&id=1064 (accesed 12 February 2016).

11. Nechaeva V. S. Iz vospominaniy ob istorii osnovaniya pervogo muzeya F. M. Dostoevskogo [Recollections of the History of the Foundation of the First Museum of F. Dostoevsky]. Dostoevskiy. Materialy i issledovaniya [Dostoevsky. Materials and Researches]. Leningrad, Nauka Publ., 1985, vol. 6, pp. 274-295.

12. Opisanie rukopisey F. M. Dostoevskogo [The Description of Fyodor Dostoevsky's Manuscripts]. Moscow, USSR Academy of Sciences Publishing House, 1957. 588 p.

13. Primechaniya A. G. Dostoevskoy k sochineniyam F. M. Dostoevskogo [The Notes of A. G. Dostoevskaya to F. M. Dostoevsky's Writings]. Grossman L. P. Seminariy po Dostoevskomu: materialy, bibliografiya i kommentarii [Grossman L. P. A Seminar on Dostoyevsky: Materials, Bibliography and Comments]. Moscow, Petrograd, State Publ., 1922, pp. 54-69.

14. Primechaniya A. G. Dostoevskoy k sochineniyam F. M. Dostoevskogo [The Notes of A. G. Dostoevskaya to F. M. Dostoyevsky's Writings]. Tvorchestvo Dostoevskogo (1821-18811921) [Dostoyevsky's Creative Work (1821-1881-1921)]. Odessa, All-Ukrainian State Publishing House, 1921, pp. 29-35.

15. Yarysheva I. S. Iz istorii «Muzeya pamyati F. M. Dostoevskogo» (Muzeynaya deyatel'nost' vdovy F. M. Dostoevskogo. Po neopublikovannym materialam) [From the History of "The Museum to the Memory of F. M. Dostoevsky" (The Museum Activity of the Widow of F. M. Dostoevsky. Based on Unpublished Materials)]. Dostoevskiy i sovremennost': materialy XXII Mezhdunar. Starorusskikh chteniy 2007 g. [Dostoevsky and Modern Age: Proceedings of the 22d International Readings of Starya Russa, 2007]. Veliky Novgorod, 2008, pp. 304-309. 